\title{
Analisa Efisiensi Water Tube Boiler Berbahan Bakar Fiber Dan Cangkang Di Palm Oil Mill Dengan Kapasitas 45 Ton Tbs/Jam
}

\author{
Pesulima B. ${ }^{1}$, Tekad Sitepu ${ }^{2}$, Farel H. Napitupulu ${ }^{3}$, Syahril Gultom ${ }^{4}$, Pramio G. Sembiring ${ }^{5}$ \\ ${ }^{1,2,3,4,5}$ Departemen Teknik Mesin, Fakultas Teknik, Universitas Sumatera Utara \\ Email: batubarapesulima@ymail.com
}

\begin{abstract}
ABSTRAK
Beberapa faktor yang mempengaruhi efisiensi boiler adalah tekanan superheater, temperatur air umpan, temperatur uap, jumlah uap yang dihasilkan, jumlah konsumsi bahan bakar, dan nilai kalor pembakaran bahan bakar. Boiler mempunyai peranan penting dalam proses produksi uap, sering kali efisiensi kualitas kerja boiler diabaikan padahal peningkatan efisiensi boiler sangat penting guna mendapatkan output yang baik. Oleh sebab itu dilakukan penelitian yang bertujuan untuk mendapatkan hubungan variasi tekanan superheater dengan efisiensi boiler, hubungan variasi suhu air umpan dengan efisiensi boiler, dan hubungan variasi jumlah uap yang dihasilkan dengan efisiensi boiler. Metode analisa yang dilakukan dengan menganalisa nilai kalor bahan bakar serabut $75 \%$ + cangkang $25 \%$, dan menganalisa efisiensi water tube boiler. Dari hasil analisa yang telah dilakukan maka hubungan variasi tekanan superheater dengan efisiensi boiler tidak konstan naik melainkan naik turun, hubungan variasi suhu air umpan dengan efisiensi boiler konstan teteap, hubungan variasi jumlah uap yang dihasilkan dengan efisiensi boiler relatif naik, nilai kalor pembakaran tinggi (HHV) adalah $21323,584 \mathrm{~kJ} / \mathrm{kg}$, nilai kalor pembakaran rendah (LHV) adalah $18083,584 \mathrm{~kJ} / \mathrm{kg}$, nilai efisiensi boiler tertinggi yang dihasilkan sebesar 71,05\% dan nilai efisiensi boiler terendah yang dihasilkan sebesar 69,49\%.
\end{abstract}

Kata kunci : boiler, nilai kalor bahan bakar, efisiensi boiler.

\section{PENDAHULUAN}

Boiler mempunyai peranan yang sangat penting dalam kelangsungan kinerja dari sebuah pabrik kelapa sawit dengan kata lain bisa dikatakan sebagai jantung dari pabrik kelapa sawit. Fungsi dari boiler adalah menghasilkan uap yang digunakan untuk kebutuhan proses pabrik, dan membangkitkan listrik untuk kebutuhan pabrik maupun perumahan karyawan di sekitar pabrik.

Peralatan pabrik yang berupa sistem boiler merupakan asset yang sangat penting bagi perusahaan. Boiler disini mempunyai peranan penting dalam proses produksi uap, dimana uap ini nantinya akan digunakan untuk memutar turbin uap sebagai penghasil energi listrik untuk kebutuhan pabrik dan uap keluaran turbin digunakan untuk proses pengolahan, di Palm Oil Mill uap menjadi kebutuhan utama, dimana uap dibutuhkan untuk perebusan (sterilizer), press (digester), klarifikasi, pengolahan inti sawit, dan tangki timbun.

Apabila terjadi gangguan pada sistem boiler tersebut maka kelancaran dan kontinuitas produksi uap akan terganggu sehingga produksi minyak kelapa sawit yang dihasilkan juga akan mengalami gangguan. Untuk mengetahui kinerja boiler yang ada di Palm Oil Mill maka penulis akan menganalisa dan menghitung efisiensi boiler di perusahaan tersebut.

Disamping itu juga sering kali efisiensi kualitas kerja boiler tersebut diabaikan padahal peningkatan efisiensi kualitas kerja boiler itu sendiri akan memberikan nilai ekonomis sendiri bagi perusahaan. Oleh karena itu peningkatan efisiensi boiler ini sangat penting guna mendapatkan output yang baik [1]. 


\section{TINJAUAN PUSTAKA Pengertian Boiler}

Boiler/ketel uap merupakan bejana tertutup dimana panas pembakaran dialirkan ke air sampai terbentuk air panas atau steam berupa energi kerja. Air adalah media yang berguna dan murah untuk mengalirkan panas ke suatu proses. Air panas atau steam pada tekanan dan suhu tertentu mempunyai nilai energi yang kemudian digunakan untuk mengalirkan panas dalam bentuk energi kalor ke suatu proses. Jika air didihkan sampai menjadi steam, maka volumenya akan meningkat sekitar 1600 kali, menghasilkan tenaga yang menyerupai bubuk mesiu yang mudah meledak, sehingga sistem boiler merupakan peralatan yang harus dikelola dan dijaga dengan sangat baik [2].

Energi kalor yang dibangkitkan dalam sistem boiler memiliki nilai tekanan, temperatur, dan laju aliran yang menentukan pemanfaatan steam yang akan digunakan. Berdasarkan ketiga hal tersebut sistem boiler mengenal keadaan tekanan-temperatur rendah (low pressure/LP), dan tekanan-temperatur tinggi (high pressure/HP), dengan perbedaan itu pemanfaatan steam yang keluar dari sistem boiler dimanfaatkan dalam suatu proses untuk memanasakan cairan dan menjalankan suatu mesin (commercial and industrial boilers), atau membangkitkan energi listrik dengan merubah energi kalor menjadi energi mekanik kemudian memutar generator sehingga menghasilkan energi listrik (power boilers). Namun, ada juga yang menggabungkan kedua sistem boiler tersebut, yang memanfaatkan tekanan-temperatur tinggi untuk membangkitkan energi listrik, kemudian sisa steam dari turbin dengan keadaan tekanan-temperatur rendah dapat dimanfaatkan ke dalam proses industri [3].

Sistem boiler terdiri dari sistem air umpan, sistem steam, dan sistem bahan bakar. Sistem air umpan menyediakan air untuk boiler secara otomatis sesuai dengan kebutuhan steam. Berbagai kran disediakan untuk keperluan perawatan dan perbaikan dari sistem air umpan, penanganan air umpan diperlukan sebagai bentuk pemeliharaan untuk mencegah terjadi kerusakan dari sistem steam. Sistem steam mengumpulkan dan mengontrol produksi steam dalam boiler. Steam dialirkan melalui sistem pemipaan ke titik pengguna. Pada keseluruhan sistem, tekanan steam diatur menggunakan kran dan dipantau dengan alat pemantau tekanan. Sistem bahan bakar adalah semua perlatan yang digunakan untuk menyediakan bahan bakar untuk menghasilkan panas yang dibutuhkan. Peralatan yang diperlukan pada sistem bahan bakar tergantung pada jenis bahan bakar yang digunakan pada sistem [4].

\section{Ketel pipa air (water tube boiler)}

Pada ketel pipa air, fluida yang mengalir dalam pipa adalah air, energi panas ditransfer dari luar pipa (yaitu ruang dapur) ke air ketel. Cara kerja ketel pipa air yaitu proses pengapian terjadi diluar pipa. Panas yang dihasilkan digunakan untuk memanaskan pipa yang berisi air. Air umpan itu sebelumnya dikondisikan terlebih dahulu melalui ecomonizer. Steam yang dihasilkan kemudian dikumpulkan terlebih dahulu didalam sebuah steam drum sampai sesuai. Setelah melalui tahap secondary superheater dan primary superheater, baru steam dilepaskan ke pipa utama distribusi [5].

Karakteristik ketel pipa air:

1. Tingkat efisiensi panas yang dihasilkan cukup tinggi.

2. Kurang toleran terhadap kualitas air yang dihasilkan dari plant pengolahan air. Sehingga air harus dikondisikan terhadap mineral dan kandungan lain yang larut dalam air.

3. Boiler ini digunakan untuk kebutuhan tekanan steam yang sangat tinggi seperti pada pembangkit tenaga. 
4. Menggunakan bahan bakar minyak, dan gas untuk water tube boiler yang dirakit dari pabrik.

5. Menggunakan bahan bakar padat untuk water tube boiler yang tidak dirakit dari pabrik.

\section{METODE PENELITIAN}

\section{Analisa Efisiensi Water Tube Boiler}

Secara umum untuk perhitungan efisiensi water tube boiler metodologi yang digunakan dalam skripsi ini yaitu metode langsung, dimana metodologi ini dikenal juga sebagai 'metode input-output' karena kenyataan bahwa metode ini hanya memerlukan keluaran/output (steam) dan panas masuk/input (bahan bakar) untuk evaluasi efisiensi [5].

\section{Variabel yang Diambil}

Pada pengujian ini variabel bahan bakar yang diuji yaitu serabut kelapa sawit murni, cangkang kelapa sawit murni, dan serabut $75 \%$ + cangkang $25 \%$ kelapa sawit. Pengujian untuk mendapatkan nilai kalor bahan bakar high heating value (HHV) dan low heating value (LHV).

\section{Prosedur Pengujian}

Adapun prosedur pengujian nilai kalor bahan bakar dengan bom kalorimeter sebagai berikut:

1. Membersihkan tabung bom dari sisa pengujian sebelumnya.

2. Menimbang bahan bakar yang akan diukur dengan timbangan sebesar 0,15 gram.

3. Mengukur volume bahan bakar.

4. Menyiapkan kawat untuk penyala dengan menggulungnya dan memasangnya pada tangkai penyala yang terpasang pada penutup bom.

5. Menempatkan cawan berisi bahan bakar pada ujung tangkai penyala.

6. Menutup bom dengan kuat setelah dipasang ring-O dengan memutar penutup tersebut.

7. Mengisi oksigen kedalam bom dengan tekanan 30 bar.

8. Menempatkan bom yang telah terpasang kedalam kalorimeter.

9. Memasukan air pendingin sebanyak $1250 \mathrm{~mL}$.

10. Menutup kalorimeter dengan penutupnya.

11. Menghidupkan pengaduk air pendingin selama 5 (lima) menit sebelum penyalaan dilakukan.

12. Membaca dan mencatat suhu air pendingin.

13. Menghidupkan penyalaan.

14 .Mengaduk air pendingin selama 5 (lima) menit setelah penyalaan berlangsung.

15. Membaca dan mencatat kembali suhu air pendingin.

16. Mematikan pengaduk.

17. Menyiapkan kembali peralatan untuk pengujian selanjutnya.

18. Melakukan kembali pengukuran sebanyak 5 (lima) kali berturut-turut untuk suatu bahan bakar yang diuji/diukur. Hasil pengujian adalah harga rata-rata dari hasil kelima pengukuran yang dilakukan [6].

\section{Rumus-rumus Yang Digunakan}

Adapun rumus-rumus yang digunakan adalah sebagai berikut:

1. Nilai kalor atas (HHV) dapat dihitung dengan rumus $\mathrm{HHV}=\left(\mathrm{T}_{2}-\mathrm{T}_{1}-0,05\right) \mathrm{X} \mathrm{\textrm {C } _ { \mathrm { V } }}(\mathrm{kJ} / \mathrm{kg})[6]$. 
2.Nilai kalor bawah (LHV) dapat dihitung dengan rumus

$\mathrm{LHV}=\mathrm{HHV}-3240 \mathrm{~kJ} / \mathrm{kg}$ [6].

3. Bila dilakukan $\mathrm{n}$ kali pengujian, maka

$\mathrm{HHV}_{\text {rata-rata }}=\frac{\sum_{I=1}^{n} H H V}{n}(\mathrm{~kJ} / \mathrm{kg})[6]$.

$\mathrm{LHV}_{\text {rata-rata }}=\mathrm{HHV}_{\text {rata-rata }}-3240(\mathrm{~kJ} / \mathrm{kg})$

Dimana :

$\mathrm{T}_{1}=$ Suhu air dingin sebelum dinyalakan

$\mathrm{T}_{2}=$ Suhu air penyala

$\mathrm{C}_{\mathrm{V}}=$ Panas jenis bom kalorimeter $\left(73529,6 \mathrm{~kJ} / \mathrm{kg}^{\circ} \mathrm{C}\right)$

Kenaikan suhu akibat kawat menyala $=0,05{ }^{\circ} \mathrm{C}$

4.Efisiensi boiler dapat dihitung dengan rumus

$$
\eta_{b}=\frac{\mathrm{W}_{\mathrm{s}}\left(\mathrm{h}_{3}-\mathrm{h}_{1}\right)}{\mathrm{W}_{\mathrm{f}} \times \mathrm{LHV}}[5] \text {. }
$$

\section{ANALISA DATA DAN PEMBAHASAN Nilai Kalor Bahan Bakar}

Setelah dilakukan analisa dari percobaan yang dilakukan maka hasil pengujian sebagai berikut:

Tabel 1 Hasil analisa nilai kalor bahan bakar serabut kelapa sawit murni

\begin{tabular}{||c|c|c|c|c||}
\hline \hline No & $\begin{array}{l}\mathrm{T}_{1} \\
\left({ }^{\circ} \mathrm{C}\right)\end{array}$ & $\begin{array}{c}\mathrm{T}_{2} \\
\left({ }^{\circ} \mathrm{C}\right)\end{array}$ & $\begin{array}{c}\mathrm{HHV} \\
(\mathrm{kJ} / \mathrm{kg})\end{array}$ & $\begin{array}{c}\mathrm{LHV} \\
(\mathrm{kJ} / \mathrm{kg})\end{array}$ \\
\hline 1 & 26.13 & 26.35 & 12500.032 & 9260.032 \\
\hline 2 & 26.49 & 26.74 & 14705.92 & 11465.92 \\
\hline 3 & 26.91 & 27.18 & 16176.512 & 12936.512 \\
\hline 4 & 27.31 & 27.58 & 15441.216 & 12201.216 \\
\hline 5 & 27.76 & 28.01 & 14705.92 & 11465.92 \\
\hline \multicolumn{3}{||c|}{ Rata-rata } & 14705.92 & 11465.92 \\
\hline
\end{tabular}

Berdasarkan tabel 1 diatas, dapat dilihat bahwa nilai HHV terendah pada percobaan 1 sebesar $12500,032 \mathrm{~kJ} / \mathrm{kg}$, nilai HHV tertinggi pada percobaan 3 sebesar $16176,512 \mathrm{~kJ} / \mathrm{kg}$, nilai HHV rata-rata sebesar $14705,92 \mathrm{~kJ} / \mathrm{kg}$, nilai LHV terendah pada percobaan 1 sebesar 9260,032 kJ/kg, nilai LHV tertinggi pada percobaan 3 sebesar $12936,512 \mathrm{~kJ} / \mathrm{kg}$, dan nilai LHV rata-rata sebesar $11465,92 \mathrm{~kJ} / \mathrm{kg}$.

Tabel 2 Hasil analisa nilai kalor bahan bakar cangkang kelapa sawit murni

\begin{tabular}{|c|c|c|c|c|}
\hline No & $\begin{array}{c}\mathrm{T}_{1} \\
\left({ }^{\circ} \mathrm{C}\right)\end{array}$ & $\begin{array}{c}\mathrm{T}_{2} \\
\left({ }^{\circ} \mathrm{C}\right)\end{array}$ & $\begin{array}{l}\mathrm{HHV} \\
(\mathrm{kJ} / \mathrm{kg})\end{array}$ & $\begin{array}{c}\text { LHV } \\
(\mathrm{kJ} / \mathrm{kg})\end{array}$ \\
\hline 1 & 26.71 & 27.08 & 23529.472 & 20289.472 \\
\hline 2 & 27.24 & 27.61 & 23529.472 & 20289.472 \\
\hline 3 & 27.82 & 28.19 & 23529.472 & 20289.472 \\
\hline 4 & 28.28 & 28.66 & 24264.768 & 21024.768 \\
\hline 5 & 28.77 & 29.15 & 24264.768 & 21024.768 \\
\hline \multicolumn{3}{|c|}{ Rata-ra } & 23823.5904 & 20583.5904 \\
\hline
\end{tabular}

Berdasarkan tabel 2 diatas, dapat dilihat bahwa nilai HHV terendah pada percobaan 1,2,3 sebesar $23529,472 \mathrm{~kJ} / \mathrm{kg}$, nilai HHV tertinggi pada percobaan 4,5 
sebesar 24264,768 kJ/kg, nilai HHV rata-rata sebesar 23823,5904 kJ/kg, nilai LHV terendah pada percobaan 1,2,3 sebesar $20289.472 \mathrm{~kJ} / \mathrm{kg}$, nilai LHV tertinggi pada percobaan 4,5 sebesar $21024.768 \mathrm{~kJ} / \mathrm{kg}$, dan nilai LHV rata-rata sebesar 20583.5904 $\mathrm{kJ} / \mathrm{kg}$.

Tabel 3 Hasil analisa nilai kalor bahan bakar serabut 75\% + cangkang 25\% kelapa sawit

\begin{tabular}{|c|c|c|c|c|}
\hline No & $\begin{array}{c}\mathrm{T}_{1} \\
\left({ }^{\circ} \mathrm{C}\right)\end{array}$ & $\begin{array}{c}\mathrm{T}_{2} \\
\left({ }^{\circ} \mathrm{C}\right)\end{array}$ & $\begin{array}{c}\mathrm{HHV} \\
(\mathrm{kJ} / \mathrm{kg})\end{array}$ & $\begin{array}{c}\text { LHV } \\
(\mathrm{kJ} / \mathrm{kg})\end{array}$ \\
\hline 1 & 26.93 & 27.27 & 21323.584 & 18083.584 \\
\hline 2 & 27.44 & 27.78 & 21323.584 & 18083.584 \\
\hline 3 & 27.94 & 28.27 & 20588.288 & 17348.288 \\
\hline 4 & 28.38 & 28.73 & 22058.88 & 18818.88 \\
\hline 5 & 28.96 & 29.30 & 21323.584 & 18083.584 \\
\hline \multicolumn{3}{|c|}{ Rata-rat } & 21323.584 & 18083.584 \\
\hline
\end{tabular}

Berdasarkan tabel 3 diatas, dapat dilihat bahwa nilai HHV terendah pada percobaan 3 sebesar 20588,288 kJ/kg, nilai HHV tertinggi pada percobaan 4 sebesar $22058,88 \mathrm{~kJ} / \mathrm{kg}$, nilai HHV rata-rata sebesar 21323,584 kJ/kg, nilai LHV terendah pada percobaan 3 sebesar 17348,288 kJ/kg, nilai LHV tertinggi pada percobaan 4 sebesar $18818,88 \mathrm{~kJ} / \mathrm{kg}$, dan nilai LHV rata-rata sebesar $18083,584 \mathrm{~kJ} / \mathrm{kg}$.

\section{Analisa Efisiensi Boiler}

Setelah dilakukan analisa maka diperoleh hasil sebagai berikut:

\section{Hubungan Enthalpy Uap dengan Efisiensi Boiler}

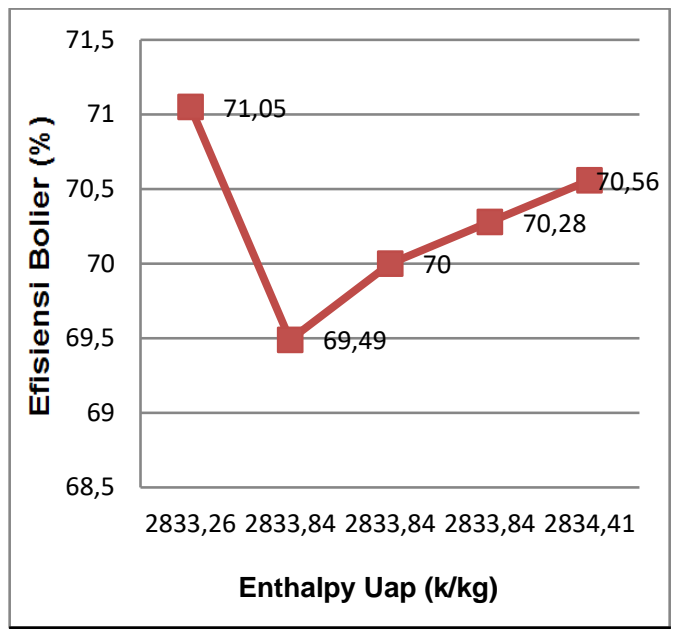

Gambar 1 Grafik hubungan enthalpy uap vs Efisiensi boiler

Berdasarkan gambar 1 diatas, dapat dilihat bahwa hubungan enthalpy uap dengan efisiensi boiler tidak konstan naik melainkan tidak teratur atau naik turun. Dimana bisa dilihat pada saat enthalpy uap $2833,26 \mathrm{kj} / \mathrm{kg}$ efisiensi boiler sebesar 71,05 $\%$, sedangkan pada saat enthalpy uap $2833,84 \mathrm{kj} / \mathrm{kg}$ rata-rata efisiensi boiler sebesar $69,92 \%$ mengalami penurunan, kemudian pada saat enthalpy uap $2834,41 \mathrm{kj} / \mathrm{kg}$ efisiensi boiler sebesar 70,56\% mengalami penaikkan. Hal ini bisa saja terjadi disebabkan beberapa faktor yang mempengaruhi bisa saja karena tekanan superheater yang tidak konstan tetap, dan temperatur daearator yang tidak stabil. 


\section{Hubungan Tekanan Superheater dengan Efisiensi Boiler}

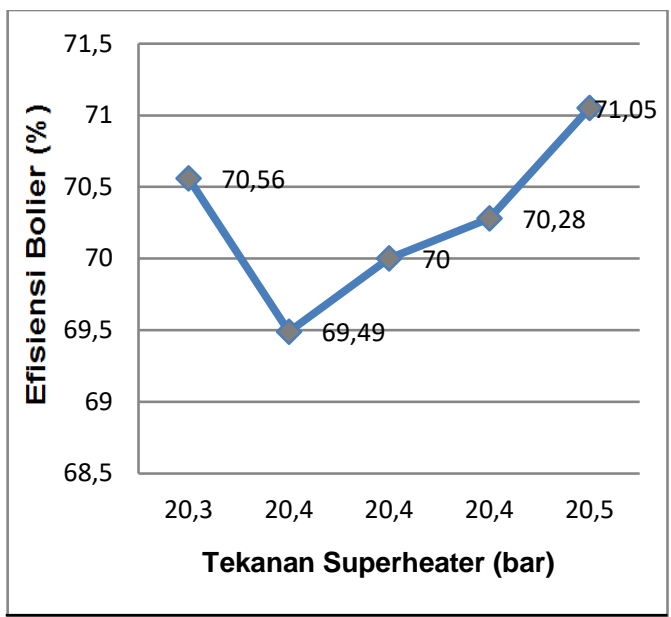

Gambar 2 Grafik hubungan tekanan superheater vs Efisiensi boiler

Berdasarkan gambar 2 diatas, dapat dilihat bahwa hubungan tekanan superheater dengan efisiensi boiler tidak konstan naik melainkan tidak teratur atau naik turun. Dimana bisa dilihat pada saat tekanan superheater 20,3 bar efisiensi boiler sebesar 70.56 $\%$, sedangkan pada saat tekanan superheater 20,4 bar rata-rata efisiensi boiler yang diperoleh sebesar 69,92 \% mengalami penurunan, kemudian pada saat tekanan superheater 20,5 bar efisiensi boiler sebesar $71.05 \%$ mengalami kenaikan.

\section{Hubungan Suhu Air Umpan dengan Efisiensi Boiler}

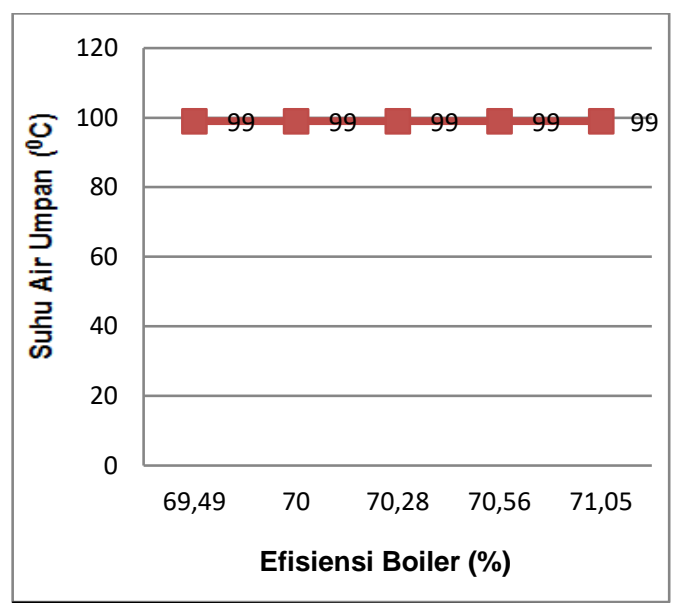

Gambar 3 Grafik hubungan suhu air umpan vs Efisiensi boiler

Berdasarkan gambar 3 diatas, dapat dilihat bahwa hubungan suhu air umpan dengan efisiensi boiler konstan tetap, dan dapat dilihat bahwa pada grafik suhu air umpan konstan dengan temperatur $99{ }^{\circ} \mathrm{C}$ perlu diketahui bahwa pada grafik suhu air umpan tersebut hasil rata-rata dari data 1 , data 2 , data 3 , data 4 , dan data 5 . Untuk hubungan suhu air umpan dengan efisiensi bisa dilihat dimana pada data 1 dengan efisiensi boiler sebesar $69.49 \%$ rata-rata temperatur $99{ }^{\circ} \mathrm{C}$, pada data 2 dengan efisiensi boiler sebesar $70 \%$ rata-rata temperatur tetap $99{ }^{\circ} \mathrm{C}$ pada data 3 dengan efisiensi boiler sebesar 71,05 \%rata-rata temperatur tetap $99{ }^{\circ} \mathrm{C}$, pada data 4 dengan efisiensi boiler 
sebesar $70,56 \%$ rata-rata temperatur tetap $99{ }^{\circ} \mathrm{C}$, dan pada data 5 dengan efisiensi boiler sebesar $70,28 \%$ rata-rata temperatur tetap $99{ }^{\circ} \mathrm{C}$.

\section{Hubungan Produksi Uap dengan Efisiensi Boiler}

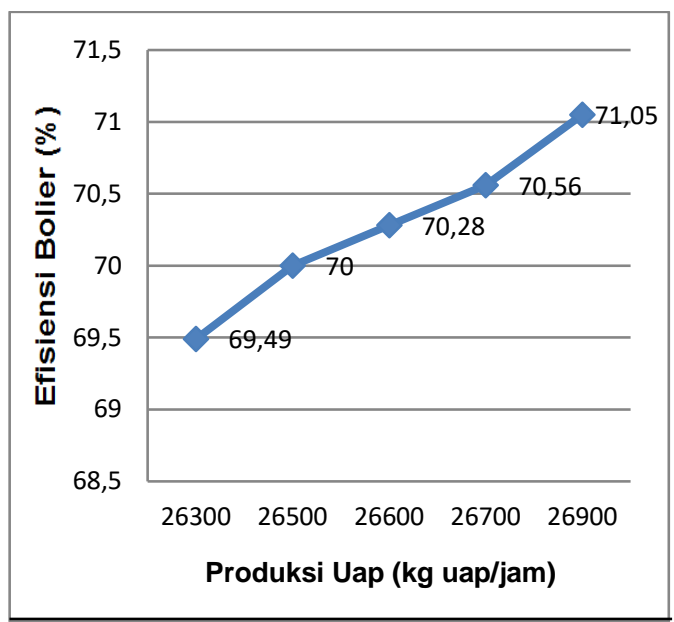

Gambar 4 Grafik hubungan produksi uap dengan efisiensi boiler

Berdasarkan gambar 4 diatas, dapat dilihat bahwa hubungan produksi uap dengan efisiensi boiler relatif konstan naik. Dimana bisa dilihat pada saat jumlah produksi uap $26300 \mathrm{~kg}$ uap/jam efisiensi boiler sebesar 69,49\%, pada saat jumlah produksi uap $26500 \mathrm{~kg}$ uap/jam efisiensi boiler naik menjadi $70 \%$, pada saat jumlah produksi uap 26600 ton uap/jam efisiensi boiler naik menjadi 70,28 \%, pada saat jumlah produksi uap $26700 \mathrm{~kg}$ uap/jam efisiensi boiler naik menjadi 70,56 \%, dan pada saat jumlah produksi uap $26900 \mathrm{~kg}$ uap/jam efisiensi boiler naik menjadi 71,05\%. Bisa disimpulkan bahwa hubungan jumlah produksi uap dengan efisiensi boiler berbanding lurus, yang artinya semakin besar jumlah produksi uap maka semakin besar efisiensi boiler yang dihasilkan.

\section{KESIMPULAN}

Berdasarkan analisa yang telah dilakukan, maka dapat disimpulkan beberapa hal, antara lain:

1. Nilai efisiensi water tube boiler terendah yang dihasilkan sebesar $69,49 \%$, dan nilai efisiensi water tube boiler tertinggi yang dihasilkan sebesar 71,05\%.

2. Membandingkan efisiensi boiler saat baru dengan keadaan sekarang mengalami penurunan, efisiensi boiler saat baru sebesar 90,9 \% sedangkan efisiensi boiler dengan keadaan saaat ini mengalami penurun menjadi sebesar 69,49\%-71,05\%.

3. Hubungan variasi tekanan superheater dengan efisiensi boiler tidak konstan naik melainkan naik turun.

4. Hubungan variasi suhu air umpan dengan efisiensi boiler konstan tetap.

5. Hubungan variasi jumlah uap yang dihasilkan dengan efisiensi boiler relatif konstan naik.

6. Nilai rata-rata yang diperoleh dari boiler untuk:

- Steam pressure superheater $: 20,4$ bar

- temperatur feed tank : $65^{\circ} \mathrm{C}$

- temperatur daerator $\quad: 99^{\circ} \mathrm{C}$

- temperatur out let steam $\quad: 225^{\circ} \mathrm{C}$

- steam flow : 26,6 ton uap/jam

7. Nilai kalor bahan bakar serabut $75 \%$ + cangkang $25 \%$ kelapa sawit: 
- Nilai kalor pembakaran tinggi (HHV) $\quad H H V=21323,584 \mathrm{~kJ} / \mathrm{kg}$

- Nilai kalor pembakaran rendah (LHV) $\quad$ LHV $=18083,584 \mathrm{~kJ} / \mathrm{kg}$

\section{SARAN}

Adapun saran-saran yang dapat diajukan pada palm oil mill maupun pembaca untuk menyempurnakan penelitian tentang analisa efisiensi water tube boiler berbahan bakar fiber dan cangkang untuk kedepan ialah sebagai berikut:

1. Untuk mengurangi penurunan efisiensi boiler lakukan pengontrolan terhadap kandungan air pada feed water sebelum masuk ke deaerator.

2. Lakukan pengecekan katup-katup yang ada pada boiler, harus diperhatikan bahwa semua katup dapat berfungsi dengan baik.

3. Untuk meningkatkan efisiensi boiler lakukan pengecekan secara berkala, dan pembersihan pipa-pipa boiler secara berkala.

4. Untuk meningkatakan efisiensi boiler kandungan air yang berlebihan pada bahan bakar untuk diperhatikan.

5. Temperatur air umpan supaya lebih diperhatikan.

\section{DAFTAR PUSATAKA}

[1] http://www.scribd.com/doc /28323850/Pengetahuan-Umum- Boiler

[2] Bahan Kuliah Ketel Uap FT USU Medan

[3] Tambunan., 1984, Ketel Uap, Karya Agung, Jakarta.

[4] Djokosetyardjo, IR. M. J, 2003, Ketel Uap, Cetakan Kelima, Pradnya Paramita. Jakarta.

[5] Muin A. Syamsir. 1988. "Pesawat-pesawat Konversi Energi I (Ketel Uap)". Edisi Pertama. Penerbit CV. Rajawali. Jakarta.

[6] Panduan Percobaan Bom Kalorimeter Laboratorium Mesin FT USU Medan 